\title{
Effectiveness of distance education using mobile applications on performance level some sports activities in P.E. lesson
}

*Abdallah Abdel Halim Mohamed

Abstract

The study aimed to using distance education through WatsApp messenger application via the educational group and monitor its effectiveness on performance level some sports activities of P.E. lesson (Skills of: shooting in basketball "the free throw", underhand serve in volleyball and running with the ball in handball) for preparatory stage pupils. the researcher used the experimental method by the experimental design of one group using pre-post measurements, the study was conducted on a sample of (20) pupils of preparatory stage with $33.33 \%$ of the total population in the year 2016/2017, results indicated that distance education via the educational group (through WatsApp application) led to a higher level of skills under research.

Keywords: Distance education, Educational group, Applications, WatsApp, P.E. lesson, Volleyball, Basketball, Handball.

Distance education, or distance learning, sometimes called e-learning, is a formalized teaching and learning system specifically designed to be carried out remotely by using electronic communication. Because distance education is less expensive to support and is not constrained by geographic considerations, it offers opportunities in situations where traditional education has difficulty operating. Students with scheduling or distance problems can benefit, because distance education can be more flexible in terms of time and can be delivered virtually anywhere. [23]

Distance education can truly be defined as the way of getting education without visiting a school or attending a class physically. Earlier the material

* Department of Teaching Methods, Faculty of Physical Education, Sadat City University, Egypt. 
related to the distance education course was delivered through mail but due to increasing use of internet and technological advancements today it is available on your computer or mobile screen with the help of various tools like email, multi-media learning tools, interactive communication Such as networks, educational groups, educational packages and video conferencing tools like ezTalks Cloud Meeting etc. [50]

Distance education is the delivery of instruction and the fulfillment of course work from remote locations; allowing instructors and students to interact without being in the same place. New technologies have made distance education an increasingly popular option for institutions and students alike. The Internet, e-mail, educational groups, video conferencing, and other interactive systems allow schools to experiment with unique modes of teaching and learning, use resources that do not reside on their own campuses, and attract faculty and students who are far from campus or cannot travel to campus very often. The first Open University is United Kingdom Open University (UKOU) that was established in the late 1960s and initially utilized television and radio as its main methodologies. Now a days almost all open universities use distance education technologies as basic teaching approach. [38]

Now, the advent of the educational groups, the internet, Social networks and widespread use of the mobiles \& computer has led to a huge growth in distantly delivered tuition and study. [47]

With the development of technology, distance education is becoming increasingly popular in students' education. A learner can complete a large amount of the classes at convenience. Most of the classes under distance education programs don't require even to attend a session at a particular time and place. A learner can do and review the assignments and can do homework at its convenience. [42]

Information technology made the whole affairs very easy as online or networks classes solved all possible 
convenience concerns. Through use of technology it becomes easier to quickly look through study materials and can be well mastered. Distance education is so designed that it allows a learner focus more strongly on curriculum, time and effort in fields that contain new information and proficiency. Distance education also allows a learner to obtain study materials at convenience and amount at a faster speed against that of slow pace of the normal classroom settings. The learners join conversations in the discussion areas with flexibility and get instant feed back in form of reviews from networks or online classmates' comments. [14]

Distance education will remain distinctive in future as well as an innovative approach for electronically delivering, well-designed, learner oriented at anywhere, anytime through use of the internet. Distance education will remain as part of E learning, web based learning through virtual classrooms and digital teamwork, where contents will continue to be delivered through internet, audio, video tape, and conferencing through video; satellite and etc. [19]

$\mathrm{He}$ rapid and intense use

of Information and communication Technology in education will continue to play a role in developed countries facilitating them to establish more and more information and communication technology based universities. [52]

Although distance education is not a new trend, but has got a huge increase due to developing technology. Distance education delivery will finally emerge as strong education approach with use of phone, desktop and TV at a same time in future. When distance education commenced using information technology, it was not well accepted and the equipment needed to provide it was expensive. That has now radically changed. And technology is being well used in video, audio text, graphics, animation, and simulation. Distance education is undergoing huge transformation and has and will never reach to a stage of saturation as much is yet to be explored and presented in this field. New and well established institutions are coming up with latest equipment and large data base to provide distance education to a growing population that wants higher 
education out of traditional classroom setting. [18]

Benefits of Distance education Tabor, Sharon (2011) [50] points to the henefits of distance educationas follows:

* Adaptability and Freedom:

One of the main advantages of distance education can be the personalized approach to get education regardless of the channels or mediums you are using for this purpose. Whether you are getting study materials online or through post you can learn only when a connection is developed between the material of the course and you. You get freedom to deal with the study material in distance education process. You can plan your learning process as per your convenience instead of sticking with a fixed schedule.

\section{* Self-inspiration:}

The distance education encourages you tom motivate yourself to learn due to the absence of a tradition teacher to guide you. You will have to create a learning environment and control it effectively so that a band of self-motivation develops in you to inspire you to learn for your personal growth. You can cultivate this band in you by engaging yourself in distance education methods.

\section{* Flexibility to Choose:}

You will have to follow a set schedule of learning as per the curriculum of the school if you are following traditional ways of learning. But different types of distance education allows you to set your learning schedule as per your convenience without following a regular schedule of learning. Even if you are out of touch form learning process, distance education program offers you flexibility to choose your course of learning.

\section{* Easy to Access:}

If you cannot attend regular classes due to various reasons like time constraints and distance etc. then distance education can be the best option for you to access the benefits of your education. If you opt for correspondence course for distance education then you will have to make postal delivery as a connection between you and your distance education center. But if you have a computer and internet connection then you can opt for an online learning method by using some video conferencing software like ezTalks cloud Meeting etc. It will allow you to interact with your teachers 
face-to-face to resolve your problems. Moreover you can continue learning even without taking leave from your job.

* Earn While You Learn:

Those who want to improve their resume by getting higher education and without breaking their existing job then distance education can be the best option for them. You can go on earning your livelihood along with improving your qualification as distance education will accommodate both, learning as well as earning.

* Saves Money and Time Both:

By joining a distance education course you can save money and time spent in travelling to nearby educational institution. Distance education allows you to access your learning center online without any additional cost. Moreover the course offered at distance education centers are cheaper than the courses provided at traditional education centres.

* Easy Access to the Experts:

The students in traditional classes have limited options to guide them but distance education by video conferencing will provide you expanded opportunities to access the experts in your course even if they are not located in your town or country. They can easily get connected with you from any part of the world to share their expertise and experiences with you. Such facility is not possible in traditional classrooms.

* Communicate with Other Educational Institutions:

You can also be in touch with several other e-schools by getting distance education through video conferencing software. You can also connect with the students located at far of locations from you, anywhere in the world, to mutually share the experiences and problems along with solving problems of each other. The distance education through video conferencing also allows you to hone your interactive skills by collaborating with others from different work environments and cultures. Such facilities will not be available in traditional classroom education system. [50]

Thus, orstance
education, or distance
education, is a field of
education that depends on the 
Information technology, and instructional systems that plan to provide learning to students who are physically not present in a class room setting. In stead of attending courses personally, teachers and students communicate at times of their convenience and choosing and exchange printed or electronic material through any suitable technology; There are many different methods that are used in the distance education. The most popular and effective are e-mails, forums, faxes, educational groups, audio and video recordings, print materials, web and video conferencing, internet radio, telephone, live streaming and much more others. [52]

Therfore, this study is based using of distance education via an educational group through WatsApp application, which offered content of lessons for the purpose of learning some skills in P.E. lesson, The researcher observation through his supervision of schools that methods and means used to skills learning in general lacks the motivation of the learner and the desire to learn more skills, as period after using these methods the learner sense monotony and boredom, these traditional methods doesn't commensurate with what the world reached of technological uses and applications in the educational process.

Thus, through the practical observation, the researcher noted that sports activities skills's for preparatory stage pupils of P.E. lesson in is characterized by randomness, poor performance and lack of coordination in motor sequence, and pupils cannot develop a correct perception of the skills in mind which leads to weak performance level in some sports activities of P.E. lesson.

Therefore, this study is an attempt to raising the level of pupils' performance with one of the most modern methods in the field of P.E. lesson, by using distance education via an educational group for studying its effect on some sports activities of P.E. lesson.

\section{Objective:}

The aim of this study was studying effect of using distance education via an educational group (through WatsApp messenger application) on performance level some sports activities of P.E. lesson for preparatory stage pupils (performance level of; Shooting "the free throw" skill in basketball, Underhand serve skill in volleyball \& Running with the ball skill in handball).

\section{A research hypothes:}


There are statistically significant differences between the average of the pre-and postmeasurements for research group in the level of skills performance under research in favor to the post measurement.

\section{Methodology \\ Method:}

The
approach was used for one
group, using pre- post
measurements.

\section{Research sample:}

The research society consisted of 60 pupils in the second graders in Sadat City Languages School - City Sadat for the year 2016/2017. The basic sample was randomly selected from the pupils of the research society. The total number of the sample was (20) pupils with $33.33 \%$ of the total population. And (15) pupils by $25 \%$ of the total research community and outside the basic research sample as exploration sample. Thus, the basic sample and outside the basic research sample consisted of (35) pupils by $58.33 \%$ of the total population.

\section{Tools:}

1- Data recording forms: Forms for recording the data for the research sample were prepared. (Appendix 1)

2- Tools and devices: Restameter device for measuring height and weight, distance tape measure, bearings, medical balls, tennis balls, volleyballs, basketballs and handballs.

3- Fitness elements tests: (Appendix 2, 3) The fitness elements tests for the skills under research were identified through the following references:

* Basketball: (Mohamed, Abdel-Dayem 2009) [37], (Mohamed 2003) [35], (Ahmed 2014) [4], (Hassan, Nahar 2012) [17], (Moustafa 2007) [40], (Gamal, El-Deeb 2008) [16].

* Volleyball: (Ahmed 2013) [5], (Zaki 2012) [55], (Farid et al. 2012) [15], (Mohamed, Hamdy 2005) [36], (Mohamed Alhefnawi 2013) [31], (Ayman 2006) [13], (Tarek, Ayman 2006) [51], (Mohamed, Ayman 2005) [32], (Ayat 2009, 2016) [10,11], (Ali 2014) [9], (Ahmed, Ali 2005) [3], (Marwan 2012) [30], (Ali 2010) [8], (Ayat, Eman 2016) [12] and (Rehab et al. 2013) [46].

* Handball: (Sobhy 2012) [48], (Kamal, Mohamed 2001) [22], (Kamal 2003) [21], (Mohamed Nasr 2016) [33].

These references were used to identify:

- Fitness elements needed to perform the skills under research.

- Measurement tests for the fitness elements (physical tests).

The experts' opinion (Appendix 6) was reviewed. 
The experts pointed out that the fitness elements (accuracy, strength, capacity, coordination, and flexibility) Shown in Appendix (2).

The experts also pointed to the most appropriate tests (Table 1 \& Appendix 3) for measuring these physical elements, which obtained an agreement rate higher than75\%as follows:

- Aiming at overlapping rectangles test. (Arm accuracy)

- The fist strength using the dynamometer test. (Strength)

- Push a medical $3 \mathrm{~kg}$ ball a distance test. (Arm capacity or Arm power) "Power $=$ speed $\&$ strength"

- The vertical jump (Jump up) to measure the muscular capacity of the legs. (Legs capacity or Legs power) "Power = speed \& strength"

- Through tennis ball on wall and receive it test. (Coordination)

- Trunk bending forward down (Standing. folding) test. (Flexibility)

- Zigzag running or the winding run test (Running between impedes). (Agility).

- 50 metre Sprint test. (Speed)

4- Skillful tests: Through the following scientific studies and references: Basketball; (Marzouk 2011) [29], (Abdel-
Nasser 2016) [1], (Mohamed, Abdel- Dayem 2009) [37], (Mohamed 2003) [35], (Ahmed 2014) [4], (Hassan, Nahar 2012) [17], (Moustafa 2007) [40] and (Gamal, El-Deeb 2008) [16]. Volleyball; (Ali 2014) [9], (Ahmed, Ali 2005) [3], (Ayman 2006) [13], (Tarek, Ayman 2006) [51], (Mohamed, Ayman 2005) [32], (Ayat 2009, 2016) [10,11], (Marwan 2012) [30], (Rehab et al. 2013) [46], (Afaf et al. 2014) [2], (Ayat, Eman 2016) [12] and (Mohamed, Hamdy 2005) [36]. Handball; (Sobhy 2012) [48], (Kamal, Mohamed 2001) [22], (Kamal 2003) [21], (Abdel-Nasser 2016) [1] and (Mohamed Nasr 2016) [33]. The skillful tests were determined to measure performance level of the skills under research. In addition, the expert opinion (Appendix 6) was used to determine the tests to measure the skills, Experts agreed to the tests of (Shooting "the free throw" test in basketball, Accuracy of underhand serve test in volleyball, Running with the ball test in handball) as shown in Table (1) \& Appendix (4).

Table (1)

Percentage of experts' agreement on physical, skillful tests $(\mathrm{N}=3)$ 


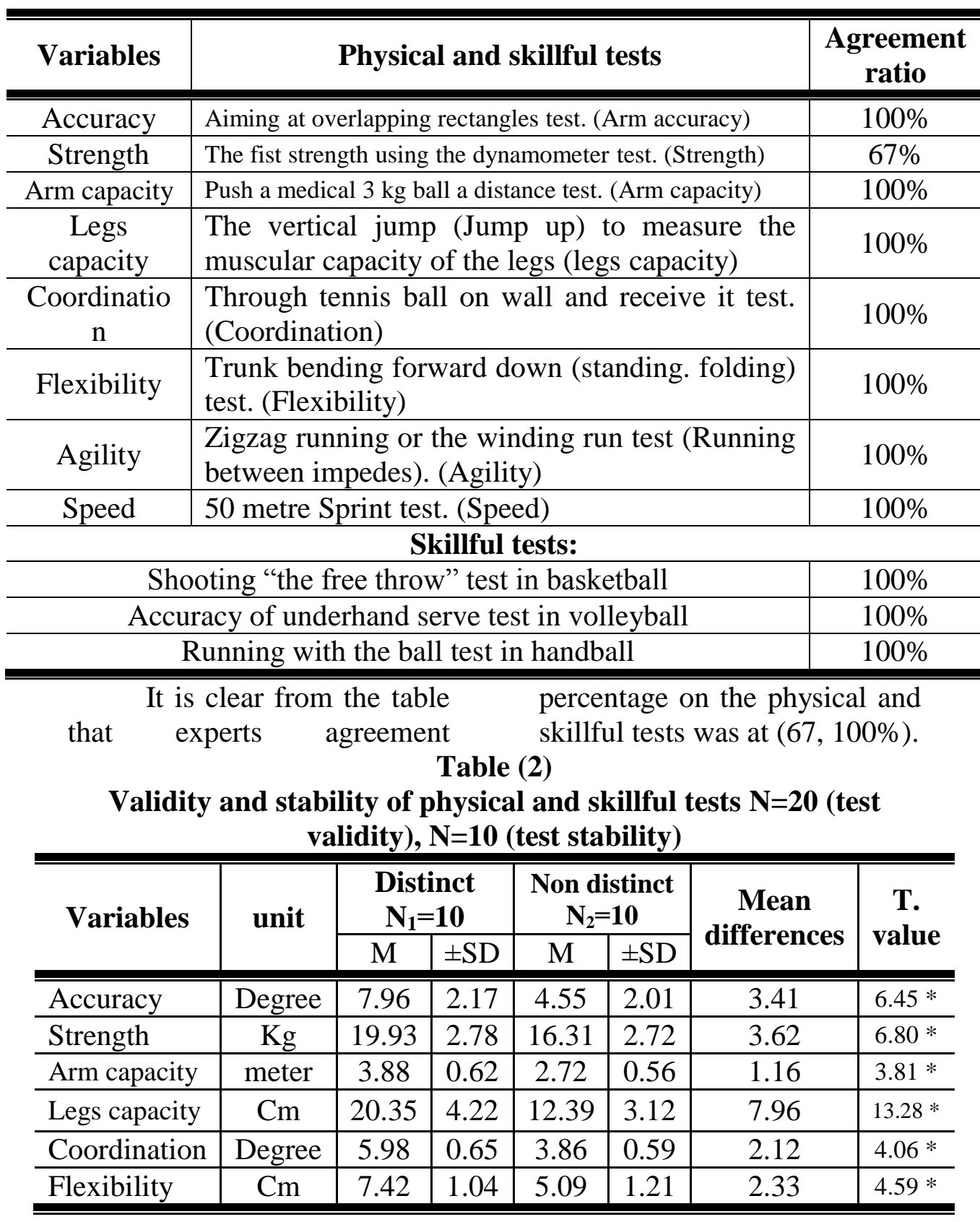

Follow Table (2)

Validity and stability of physical and skillful tests $\mathbf{N = 2 0}$ (test

Assiut Journal For Sport Science Arts 
validity), $\mathrm{N}=10$ (test stability)

\begin{tabular}{|c|c|c|c|c|c|c|c|}
\hline \multirow[t]{2}{*}{ Variables } & \multirow[t]{2}{*}{ unit } & \multicolumn{2}{|c|}{$\begin{array}{c}\text { Distinct } \\
\mathrm{N}_{1}=10\end{array}$} & \multicolumn{2}{|c|}{$\begin{array}{c}\text { Non distinct } \\
\mathbf{N}_{2}=10\end{array}$} & \multirow{2}{*}{$\begin{array}{c}\text { Mean } \\
\text { differences }\end{array}$} & \multirow{2}{*}{$\begin{array}{c}\text { T. } \\
\text { value }\end{array}$} \\
\hline & & $\mathrm{M}$ & $\pm \mathrm{SD}$ & $\mathrm{M}$ & $\pm \mathrm{SD}$ & & \\
\hline Agility & econd & 10.04 & 2.02 & 13.67 & 2.04 & 3.63 & $6.91 *$ \\
\hline Speed & Second & 9.95 & 1.55 & 14.43 & 1.42 & 4.48 & $7.96 *$ \\
\hline \multicolumn{8}{|c|}{ Shooting "the free throw" test in basketball } \\
\hline & Degree & 12.57 & 2.8 & 5.95 & 2.04 & 6.62 & $11.57 *$ \\
\hline \multicolumn{8}{|c|}{ Accuracy of underhand serve test in volleyball } \\
\hline & Degree & 12.84 & 1.61 & 7.35 & 2.99 & 5.49 & $9.75 *$ \\
\hline \multicolumn{8}{|c|}{ Running with the ball test in handball } \\
\hline & Degree & 39.25 & 5.68 & 22.58 & 5.21 & 16.67 & $24.63 *$ \\
\hline \multirow{2}{*}{ Variables } & \multirow{2}{*}{ unit } & \multicolumn{2}{|c|}{$\mathbf{1}_{\mathrm{st}}$} & \multicolumn{2}{|c|}{$2_{\text {n.d }}$} & \multirow{2}{*}{\multicolumn{2}{|c|}{$\mathrm{CC}$}} \\
\hline & & $\mathrm{M}$ & $\pm \mathrm{SD}$ & $\mathrm{M}$ & $\pm \mathrm{SD}$ & & \\
\hline Accuracy & Degree & 4.55 & 2.01 & 4.62 & 2.15 & $0.91 *$ & \\
\hline Strength & $\mathrm{Kg}$ & 16.31 & 2.72 & 16.29 & 2.65 & $0.93 *$ & \\
\hline Arm capacity & meter & 2.72 & 0.56 & 2.71 & 0.54 & $0.96 *$ & \\
\hline Legs capacity & $\mathrm{Cm}$ & 12.39 & 3.12 & 12.41 & 3.17 & $0.94^{*}$ & \\
\hline Coordination & Degree & 3.87 & 0.59 & 3.91 & 0.62 & $0.94 *$ & \\
\hline Flexibility & $\mathrm{Cm}$ & 5.09 & 1.21 & 5.13 & 1.25 & $0.95 *$ & \\
\hline Agility & Second & 13.67 & 2.04 & 13.64 & 2.02 & $0.93^{*}$ & \\
\hline Speed & Second & 14.43 & 1.42 & 14.46 & 1.44 & $0.92 *$ & \\
\hline
\end{tabular}

Shooting "the free throw" test in basketball

\begin{tabular}{|l|l|l|l|l|l}
\hline Degree & 5.95 & 2.04 & 6.05 & 2.12 & $0.89^{*}$ \\
\hline
\end{tabular}

Accuracy of underhand serve test in volleyball

\begin{tabular}{|l|l|l|l|l|l}
\hline Degree & 7.35 & 2.99 & 7.42 & 3.02 & $0.91^{*}$ \\
\hline
\end{tabular}

Running with the ball test in handball

\begin{tabular}{|l|l|l|l|l|l|} 
Degree & 22.58 & 5.21 & 22.56 & 5.17 & $0.95^{*}$ \\
\hline
\end{tabular}

The value of $\mathrm{t}$-table at a significant level $(18,0.05)=$ 2.10 (two directions), the $\mathrm{t}-$ value (cc) at a significant level $(8,0.05)=0.738$ (two directions) Sperman

It is clear from Table (2) that there are statistically significant differences between the two distinct and non- 
distinct groups, indicating the validity of the tests. It is also evident that there is a correlation between the first and second applications indicating the stability of the tests.

\section{Distance education style design through WatsApp messenger application:}

Distance education style was designed via the educational group as shown below:

1- Objective of Distance education style: The distance education style through the educational group was aimed to know its effect on the performance level of (Shooting in basketball, Underhand serve in volleyball and Running with the ball in handball) for preparatory stage pupils.

2- Skillful level of the research sample: The skillful aspects was determined by the tests under research (Appendix 4).

3- Distance education style content: The distance education style content was determined through the following scientific references (Ayman 2006)[13], (Tarek, Ayman 2006)[51], (Mohamed, Ayman 2005) [32], (Suzanne 2007) [49], (Ayat
2009, 2016) [10,11], (Rehab et al. 2013) [46], (Afaf et al. 2014) [2], (Mohamed, Hamdy 2005)[36], (Ali 2014) [9], (Ahmed, Ali 2005) [3], (Marwan 2012) [30], (Ali 2010)[8], (Zaki 2012) [55], (Farid et al. 2012) [15], (Mohamed Alhefnawi 2013) [31], (Mahmoud 2016a,b) [26,27], (Marzouk 2011) [29] and (Abdel-Nasser 2016) [1] by including some multimedia; videos, pictures and texts in an educational group contains skillful aspects of Shooting in basketball, Underhand serve in volleyball and Running with the ball in handball skills. The stages of the technical performance of the skills under research were described (Appendix 5).

4- The educational group: An educational group was designed or created contain the reading and seing the explanation, information and educational videos of the skillful aspects of the skills under research on the WhatsApp.

WhatsApp Messenger was chosen because of dealing ease with it and the spread of its use in mobile phones between pupils. Therefore, the 
possibility of easily browsing at any time and from anywhere.

5- Style of teaching: The instructional style was used in the study was the individual or self-learning style through the use of each puiple for the educational group (WhatsApp Messenger) by individually.

6- The educational group features:

- All pupils can communicate with each other in the educational group.

- Display and download text, images, graphics and video.

- Sound control during video playback.

-Repetition of images, graphics and video more than once.

- Pause during video playback.

7- The experts' opinion: The experts' opinion (appendix 6) of distance education style and

Table (3)

Time distribution of the research group

\begin{tabular}{l|l}
\hline \multicolumn{1}{c|}{ Content } & \multicolumn{1}{c}{ Time } \\
\hline \hline Application Duration & 12 weeks \\
\hline Number of units (lessons) per week & 2 units in week \\
\hline Total number of units & 24 units \\
\hline Unit time & $\begin{array}{l}\text { Open time (Time } \\
\text { available 24 hours a day) }\end{array}$ \\
\hline \hline \begin{tabular}{l} 
Distribution of the the total units for the \\
educational content (skills) \\
Assiut Journal For Sport Science Arts \\
\cline { 2 - 2 }
\end{tabular} \\
\begin{tabular}{|l} 
research group: \\
\hline
\end{tabular}
\end{tabular}

agreement was obtained on the educational group was designed, and the experts agreed to instructions and contents of the group.

8- The exploratory study: The distance education style was tested by presenting the educational group (WhatsApp) on the sample of the exploratory study in order to identify the clarity of the pictures, drawings and video were contained on the educational group. The result of this experiment was the clarity of all the contents of the distance education style on the educational group.

\section{Application:}

Distance education style was implemented on the basic study sample (50 pupils), as shown in table (3): 
The research group was study by the distance education style via the educational group,
Table (4) shows the distribution of educational content of the research group.

Table (4)

Distribution of the educational content (the skills under research) on the total units for the research group

\begin{tabular}{c|c|l}
\hline \hline Week & Units & $\begin{array}{c}\text { The educational content (Study content) on } \\
\text { the educational group }\end{array}$ \\
\hline \hline 1 & 1,2 & Shooting in basketball "the free throw" \\
\hline 2 & 3,4 & Shooting in basketball "the free throw" \\
\hline 3 & 5,6 & Underhand serve in volleyball \\
\hline 4 & 7,8 & Underhand serve in volleyball \\
\hline 5 & 9,10 & Running with the ball in handball \\
\hline 6 & 11,12 & Running with the ball in handball \\
\hline 7 & 13,14 & Shooting in basketball "the free throw" \\
\hline 8 & 15,16 & Underhand serve in volleyball \\
\hline 9 & 17,18 & Running with the ball in handball \\
\hline 10 & 19,20 & Shooting in basketball "the free throw" \\
\hline 11 & 21,22 & Underhand serve in volleyball \\
\hline 12 & 23,24 & Running with the ball in handball \\
\hline \hline
\end{tabular}

\section{Moderation of sample distribution:}

Table (5)

Distribution moderation for basic and exploratory research sample $(\mathbf{N}=70)$

\begin{tabular}{l|c|c|c|c|c}
\hline \hline \multirow{2}{*}{ Parameters } & \multirow{2}{*}{ Unit } & \multicolumn{5}{c}{ Statistical analyses } \\
\cline { 3 - 6 } & & Mean & Median & SD & SK \\
\hline \hline Age & year & 13.14 & 13.00 & 0.54 & 0.78 \\
\hline Hight & $\mathrm{Cm}$ & 141.71 & 142.00 & 8.50 & -0.10 \\
\hline Wight & $\mathrm{Kg}$ & 40.84 & 41.00 & 6.95 & -0.07 \\
\hline Physical Tests: & degree & 4.54 & 4.60 & 2.00 & -0.09 \\
\hline Accuracy & Kg & 16.32 & 16.50 & 2.75 & -0.20 \\
\hline Strength & meter & 2.71 & 3.00 & 0.54 & -1.61 \\
\hline Arm capacity & \multicolumn{5}{|l}{} \\
\hline \hline
\end{tabular}

Table (5) 
Distribution moderation for basic and exploratory research sample $(\mathbf{N}=70)$

\begin{tabular}{l|c|c|c|c|c}
\hline \multirow{2}{*}{\multicolumn{1}{c|}{ Parameters }} & \multirow{2}{*}{ Unit } & \multicolumn{4}{c}{ Statistical analyses } \\
\cline { 3 - 6 } & & Mean & Median & SD & SK \\
\hline \hline Legs capacity & $\mathrm{Cm}$ & 12.41 & 12.00 & 3.14 & 0.39 \\
\hline Coordination & degree & 3.91 & 4.00 & 0.61 & -0.44 \\
\hline Flexibility & $\mathrm{Cm}$ & 5.07 & 5.00 & 1.19 & 0.18 \\
\hline Agility & Second & 13.69 & 14.00 & 2.05 & -0.45 \\
\hline Speed & Second & 14.44 & 14.50 & 1.41 & -0.13 \\
\hline Skillful Tests: & \multicolumn{5}{|c}{} \\
\hline $\begin{array}{l}\text { Shooting "the free throw" } \\
\text { test in basketball }\end{array}$ & degree & 5.97 & 6.00 & 2.06 & -0.04 \\
\hline $\begin{array}{l}\text { Accuracy of underhand } \\
\text { serve test in volleyball }\end{array}$ & degree & 7.40 & 7.50 & 3.01 & -0.10 \\
\hline $\begin{array}{l}\text { Running with the } \\
\text { ball test in handball }\end{array}$ & degree & 22.56 & 23.00 & 5.20 & -0.25 \\
\hline \hline
\end{tabular}

\begin{tabular}{ll}
\hline \hline Table (5) shows that the & 3 ), indicating the moderated \\
values of Skewness & distribution of the basic and \\
coefficients ranged from $(+3,-$ & exploratory sample.
\end{tabular}

Results

Table (6)

Significance of the mean differences between the pre- post measurements of the research group in the performance level of (Shooting in basketball, Underhand serve in volleyball and Running with the ball in handball) skills

\begin{tabular}{|c|c|c|c|c|c|c|}
\hline \multirow{3}{*}{ Parameters } & \multicolumn{4}{|c|}{$\begin{array}{c}\text { Resparch orninn } \\
\text { (distance education } \\
\text { style) } \mathbf{N}=\mathbf{2 0}\end{array}$} & \multirow{3}{*}{$\begin{array}{c}\text { Mean } \\
\text { Differences }\end{array}$} & \multirow{3}{*}{$\begin{array}{c}\text { T. } \\
\text { value }\end{array}$} \\
\hline & \multicolumn{2}{|c|}{ Pre } & \multicolumn{2}{|c|}{ Post } & & \\
\hline & $\mathbf{M}$ & $\mathbf{S D} \pm$ & $\mathbf{M}$ & SD \pm & & \\
\hline \multicolumn{7}{|c|}{ Shooting "the free throw" test in basketball } \\
\hline & 5.97 & 2.06 & 11.40 & 2.64 & 5.43 & $8.47 *$ \\
\hline \multicolumn{7}{|c|}{ Accuracy of underhand serve test in volleyball } \\
\hline & 7.40 & 3.01 & 10.92 & 2.93 & 3.52 & $4.23 *$ \\
\hline \multicolumn{7}{|c|}{ Running with the ball test in handball } \\
\hline & 22.56 & 5.20 & 29.88 & 5.42 & 7.32 & $11.67 *$ \\
\hline
\end{tabular}

T Table value at a significant level $(19,0.05)=1.73$ (one direction)
Table
(6) shows
statistically
significant

Assiut Journal For Sport Science Arts 
differences between Pre-Post measurements of the research group at a significant level of 0.05 .

\section{Discussion}

The results of Table (6) show that there are statistically significant differences between pre and post mean values of thes research group in performance level some sports activities of P.E. lesson for preparatory stage pupils at a significant level $(0.05)$ for the post measurement.

These results indicate that the distance education style via the educational group was a positive effect on performance level of sports activities or the skillful level under research (Shooting in basketball, Underhand serve in volleyball and Running with the ball in handball skills). This indicates that the distance education style led to the correct perception of how to perform skills (performance level of sports activities under research). The images, drawings, texts and videos were attached to the educational group was a positive result on the level of sports activities of P.E. lesson. Also, The researcher attributed the reason for these differences to the experimental variable only, which is represented in the distance education style. The researcher also attributes the progress made to the research group to clarifying the skillful performance (Skills of: shooting in basketball, underhand serve in volleyball and running with the ball in handball) through The educational videos on the educational group. Thus, the higher level of skillful performance for the research group.

The previous results is consistent with many studies which was indicated that use of the distance education style via WhatsApp and Internet in the educational process shows an improvement and effectiveness in the learning process and the higher level of skillful performance in general, such as the study of (Ahmed Talha 2011) [7], (Ahmed Saher 2011) [6], (Rania 2008) [43], (Rasha 2007) [44], (Mar Pérez et al. 2015) [28], (Koen et al. 2015) [24], (Rehab 2011) [45] and (Jean 2015) [20].

Thus, the researcher attributed the reason of differences between pre and post 
measurements to the experimental variable only, which is the distance education style. The researcher also attributes the progress in sports activities or skills under research to relying on the distance education style via the educational group and its various media (texts, pictures, graphics, audio and video) and thus a positive effect on variables of research (Shooting, Underhand serve and Running with the ball) and this is due to the attractiveness and effectiveness of distance education style.

Accordingly,

The distance education style contribute in a positive way in improving sports activities of P.E. lesson \& skillful performance in general, and active learning using technology through WhatsApp (the educational group) contributes positively to enhance skillful variables under research.

On the other hand, The researcher attributes the progress of the experimental group to the interaction between the puiple and the learning through WhatsApp which the pupils controlled what they are subjected to and controlled the sequenceof the presentation, time. As WhatsApp help to learn according to the self-speed of each puiple, in addition to the formation of the optimal perception of the performance of skillful in how to emplement the skills under research through the educational group. Thus, provide the puiple feedback, which was helped to develop his movement perception. Therefore, the effectiveness of distance education style via the educational group, This previous results is consistent with (Magdy 2003) [25], (Osman et al. 2006) [41], (Yaseen 2006) [53], (Yogesh 2004) [54], (Mohamed, Makarem, Hany, 2001) [34] and (Moustafa 2009) [39].

Accordingly, This proves that distance education style leads to higher level of performance and learning as a result of the practice of what has been explained and presented on WhatsApp (the educational group). Thus, reflected in the level of pupils' performance. Thus, A research hypothes is achieved, which stated that there are statistically 
significant differences between the pre-and post-measurements for the research group (distance education style via the educational group through WatsApp application) in the level of skillful Performance under research (sports activities of P.E. lesson) in favor to the post measurement.

\section{Conclusions}

Distance education style via the educational group (through WatsApp messenger application) has effective on performance level some sports activities of P.E. lesson (skills of: shooting in basketball "the free throw", underhand serve in volleyball and running with the ball in handball) for preparatory stage pupils.

\section{Recommendations}

- $\quad$ Encouraging the using distance education style via the educational group because of its positive effect in raising the sports activities level of P.E. lesson (skills of: shooting in basketball "the free throw", underhand serve in volleyball and running with the ball in handball).

- Introducing learning through the distance education style within the curricula of the scientific subjects in the faculties of physical education. - Conducting further studies on the effectiveness of distance education style in other sports activities aspects.

\section{References}

1- Abdel-Nasser Mohamed Al-Abed: Technical Performance and Educational Steps of Basketball and Handball Skills, Institute of Science and Techniques of Physical and Sports Activities, at http://istaps.yoo7.com/t718topic, 16 June 2016.

2- Afaf Mohamed Khattaby, Elham Abdel-Moneim Ahmed, Dalia Mohamed Hashim: Applications in Volleyball, Helwan university press, Faculty of physical education, Helwan university 2014.

3- Ahmed Abdel-Daeim AlWazeer, Ali Moustafa Taha: Trainer's Guide in Volleyball (Tests, Planning, Records) Edition 2,Arab Thought House (Dar El-Fikr El-Araby), Cairo 2005.

4- Ahmed Amin Fawzi: Basketball History, Principles and Basic Skills, Dar Al Wafaa Printing and Publishing, Alexandria, 2014. 
5- Ahmed Rady Ella-waty:

"A training program for the development of traffic forecasting components and its impact on the performance level of some defense skills for volleyball players" Unpublished Master thesis, Faculty of Physical Education in Fleming, Alexandria University 2013.

6- Ahmed Saher Hassanein. The Impact of Using the International Information Network on Learning Some Basic Skills in Football for Students of the Second Division, Faculty of Physical Education, Menofya University. World Journal of Sport Sciences "WJSS", Vol.4 Numb. 3 , ISSN 2078 - 4724, pp:277-291. June 2011.

7- Ahmed Talha Hossam El Din: "Using E-learning in learning the subject of teaching methods" Unpublished Master thesis, Faculty of Physical Education, Sadat University 2011.

8- Ali Salloum Jawad alHakim: Tests, Measurement and Statistics in the sportiical Field, Edition 2, Al-Qadisiyah, Al-Teef for printing and publishing, Iraq 2010.
9- Ali Salman Abdel-Tarfi: Skillful tests in volleyball, Ministry of Higher Education and Scientific Research, Mustansiriya University, Iraq, at https://uomustansiriyah.edu .iq/media/lectures/13/13_2017_ 10_04!09_10_59_AM.doc, 2014.

\section{0- Ayat Abdel-Halim}

Mohamed Aly:Learning by technological modeling and its effect on the performance level of Overhead Serve skill in volleyball, Scientific Journal of Sports Sciences \& Arts. (Publications; search number 110, part 2, June 2020, ISSN 1110-8460-2020-102) at www.ijssa-gezira.com. Faculty of P.E for girls, University of Helwan, 2016.

\section{1- Ayat Abdel-Halim} Mohamed Aly, Eman AbdelHalim Mohamed Aly: The effect of different Teaching Styles on Learning some Volleyball Skills for Female P.E Students (Comparative Study). The international scientific Journal of Physical Education and Sport, Sciences, NSSN 24003, Print issn: 2356/9565, Online issn: 2356/9573, Volume (3), 98106, Faculty of Physical 
Education, Helwan University, January 2016.

\section{2- Ayman Abdu Mohamed}

Mohamed: Fundamentals of Volleyball (Theory and Practice), Happy Wright for Printing and Publishing, Assiut, 2006.

13- Bates, T.: Technology, elearning and distance education: RoutledgeFalmer. https://www.ukessays.com/essa ys/education/distance-

education-learning.php, 2005.

14- Farid Abdel-Fattah Khashaba, Hossam Khalifa, Mahmoud Metwally: Fundamentals of volleyball between theory and application, Rashid Press, second edition, Cairo, Arab Republic of Egypt. pp 45, 2012.

15- Gamal Ramadan Mousa, Hany Abdel-Aziz El-Deeb: "The effectiveness of a proposed model for designing an online course (educational site) on the aspects of learning in basketball." The Third International Scientific Conference: Development of Educational Curricula considering Recent Trends and Labor Market need. Zagazig, 22-23 March 2008.
16- Hassan Mohammed AlSamadi, Tamam Nahar AlAbd: The World of Basketball, The Arab Society Library for Publishing and Distribution, ISBN 13 978-9957-83-100-4, Kuwait, 2012.

17- Hebert, C. G.: Education Essays - Distance Education Learning, Information, UK Essays, Published: 23rd March, at

https://www.ukessays.com/essa ys/education/distanceeducation-learning.php, 2015.

18- Hedge, N. and Hayward, L.: "Redefining roles: University e-learning contributing to Life long learning in a networked world." E-Leaning, 1: (128145), 2004.

19- Jean Chastre, CharlesEdouard Luyt : Factors affecting the e-learning outcomes, Telematics and Informatics, Volume 32, Issue 4, November 2015, Pages 701719.

20- Kamal Abdel-Hamid Ismail: Children playing handball, Arab Thought House, ISBN 682225633666652, 2nd edition, Cairo, 2003.

21- Kamal Abdel-Hamid Ismail, Mohamed Sobhy Hassanein: Modern Handball 
Quadrature "The Nature and Educational Dimensions - The Foundations of Measurement and Evaluation - Physical Fitness", ISBN 977-294-2216X, The Book Center for Publishing, Cairo, 2001.

22- Kaplan, Andreas M.; Haenlein, Michael: "Higher education and the digital revolution: About MOOCs, SPOCs, social media, and the Cookie Monster". Business Horizons. 59 (4): 44150.doi:10.1016/j.bushor.2016.0 3.008. at https://whatis.techtar get.com/definition/distancelearning-e-learning, 2016.

23- Koen Aesaert, Daniël Van Nijlen, Ruben Vanderlinde, Jo Tondeur, Ines Devlieger, Johan van Braak:The contribution of pupil, classroom and school level characteristics to primary school pupils' ICT competences: A performancebased approach, Computers \& Education, Volume87, Septe mber 2015, Pages 55-69.

24- Magdy Aziz Ibrahim: Education Strategies and Learning Methods, The Anglo Egyptian Library, Cairo 2003.

25- Mahmoud Abdel-Halim Abdel-karim: School sports system - good education, teaching skills, teacher and efficiency standards, Arab Thought House (Dar El Fikr El Araby), Cairo 2016a.

\section{6- Mahmoud Abdel-Halim} Abdel-karim: School sports system - Structure and Policies, Curriculum and Curriculum, Calendar, Arab Thought House (Dar El Fikr El Araby), Cairo 2016 b.

\section{7- Mar Pérez-Sanagustín,} Pedro J. Muñoz-Merino, Carlos Alario-Hoyos, Xavier Soldani, Carlos Delgado Kloos: Lessons learned from the design of situated learning environments to support collaborative knowledge construction, Computers \& Education, Volume87, Septe mber 2015, Pages 70-82, 2015.

\section{8- Marzouk Salem}

Marzouk: Practical Education for Physical Education, Department of Curriculum and Instruction, College of Education, Umm Al-Qura University, at http://uqu-edusport.yoo7.com/t86-topic,

Saudi Arabia, 2011.

29- Marwan Abdel-Magid Ibrahim: Volleyball Scientific Encyclopedia (Skills, Plans, Physical and Skillful Tests), Edition 2, Al-Warraq Foundation for Publishing and 
Distribution, Amman, Jordan 2011, P. 198, 2012.

\section{0- Mohamed}

Mohamed

Ahmed

hafnawi:Volleyball Training, at http://www.aun.edu.eg/ arabic/membercv.php?M_ID=3 521, Faculty of Physical Education, Assiut university, 2013.

\section{1- Mohamed Kamal El-din} Al-Baroudei, Ayman Abdou Mohamed: The effect of use some teaching strategies in some fundamental skills of volley ball, Assiut university, Journal of Assiut for Science and Arts of Physical Education, 2005.

\section{2- Mohamed Nasr El-Din}

Radwan: The Entrance to Measurement in Physical Education and Sports, Book Center, Cairo 2016.

33- Mohamed Saad Zaghloul, Makarem Helmi Abu Harja, Hany Said Abdel Moneim: Education Technology and Methods in Physical Education, Book Cente, 2nd Edition, Cairo 2001.

34- Mohamed Sobhy Hassanein: Methods of Building and Standardizing Tests and Metrics in Physical Education, Arab Thought
House, 2nd edition, Cairo, 2003.

\section{5- Mohamed Sobhy}

Hassanein, Hamdy Abdel

Moneim: The scientific bases of volleyball and measurement methods for evaluating (physically. Skill. Cognitive. Psychological. Analytical), book centre for publishing, second edition, Cairo. Arab Republic of Egypt. pp 34, 2005.

36- Mohamed Sobhy Hassanein, Mohamed Mahmoud Abdel-Dayem: Modern in basketball. The scientific and applied foundations (teaching-trainingmeasurement-selection-law)

Dar Al-Fikr Al-Arabi, $2^{\text {nd }}$, ISBN 4- 1213- 10- 977, Cairo 2009.

37- Moore, Michael G.; Greg Kearsley: Distance Education: A Systems View, Second, Belmont, CA: Wadsworth. , (33-36), 2005.

38- Moustafa Abdel-Samie Mohamed: Educational Technology, Arabic Studies, 2nd Edition, Book Center Publishing, Cairo 2009.

39- Moustafa Mohamed Zidan: Encyclopedia of basketball training, Arab 
Thought House, 2nd, ISBN 70990- 10- 977, Cairo 2007.

40- Osman Mustafa Othman, Hisham Mohamed Abdel Halim, Haitham Abdelhamid Mohamed: "The design of an educational website and its impact on some the technical, cognitive and emotional variables of the Blind sport for the physicaleducation faculty students, Minia University" Journal of Sport Sciences and Arts, Faculty of Physical Education, Assiut University 2006.

41- Randall S. Hansen: Technology and Distance Learning Introduction, Distance Learning MBA, at https://www.ukessays.com/essa ys/education/distanceeducation-learning.php, 2016.

42- Rania Mohamed Hassan: "Designing an website for field and track competitions using the internet" Third International Scientific Conferenc, Faculty of Physical Educatio, Alexandria University 2008.

43- Rasha Najih Aly: "A proposed educational program through the design of a web site model and its impact on learning some skills of rhythmic exercises for for the physicaleducation faculty students, Minia University" unpublished $\mathrm{PhD}$ thesi, Facultyof Physical Education, Minia University 2007.

\section{4- Rehab Adel Gabal:} "Designing an educational program using the international information network and its impact on the implementation on the physical education lesson aspects in the light of the overall quality standards", Journal of Science and Sports Arts-Volume 39 - Faculty of Physical Education, Gizera, Helwan University, June 2011.

45- Rehab A. Gabal, Abdallah A. Mohamed and Khaled A. El-Battawy. "Effects of Teaching Strategy (cooperative learning and computer) on Learning the volleyball skills in P.E. Lesson". Journal of Physical Culture and Sport. Studies and Research, Warsaw, 24 ${ }^{\text {th }}$ of October 2013, Poland.

46- Simon Midgley: What is Distance Learning? at https://www.thecompleteuniver sityguide.co.uk/distancelearning/what-is-distancelearning/, 25 August 2016.

47- Sobhy Ahmad Qablan: Handball (Skills, Training, Injury Training) ISBN 13 978- 
9957-83-069-4, Canadian Center for Linguistic Programming and Neuroscience, 2012.

$\begin{array}{ll}\text { 48- Suzanne } & \begin{array}{c}\text { Badran } \\ \text { Sulaiman: }\end{array} \text { Volleyball, }\end{array}$
Menoufia university press, Faculty of physical education Sadat university 2007.

49- Tabor,

Sharon

W: "Narrowing the Distance: Implementing a Hybrid Learning Model". Benefits of Distance Learning, Quarterly Review of Distance Education. IAP. 8 (1): 48-49. ISBN 9787774570793.ISSN 1528-

3518. at https://www.eztalks. com/elearning/benefits-ofdistance-learning.html, Retrieved 23 January 2011.

50- Tarek Mohamed $M$. Abdel-Aziz, Ayman Abdou Mohamad Mohamad: The Effectiveness of An Educational Program Using the Computer on the Level of Skill and Feedback Among Faculty of Physical Education Volleyball Players in Assiut University, Journal of Assiut for Science and Arts of Physical Education, Volume 4, April, 2006.
51- Toor S K,: "Hybrid Model for e-Learning at Virtual University of Pakistan" The Electronic Journal of eLearning Volume 3 Issue 1, (67-76), 2005. at https://www.ukessays.com/essa ys/education/distanceeducation-learning.php, and http://samples.easygoessay.co $\mathrm{m} /$ distance-education-essay/, 20 March 2016.

\section{2- Yaseen Abdulrahman}

Kandil: Teaching aids and information technology, International Publishing House, 2rd Edition, Riyadh, Saudi Arabia 2006.

53- Yogesh Malhotra and Ranel E. Erickson. "Interactive Educational Multimedia": Coping with need for Innerving data Storage, Educational Technology, V. 34, No. 4, P. 35. 2004.

54- Zaki, M.H.: Teaching volleyball methods. Technical radiation library for publishing, Cairo. Arab Republic of Egypt. pp 40, 2012. 